\title{
Hydrochemistry applied to assess the chemical weathering and soil removal rates in the Sorocaba River basin, São Paulo State
}

\author{
Alexandre Martins Fernandes ${ }^{1}$ (D), Fabiano Tomazini da Conceição ${ }^{*}$ (D), Jeferson Mortatti ${ }^{2}$ (D)
}

\begin{abstract}
Chemical weathering and soil removal rates are responsible for the Earth's landscape, composition of surface and groundwater, producing the soils and buffering the composition of the atmosphere. This study aimed to assess the chemical weathering and soil removal rates in the Sorocaba River basin, São Paulo State, Brazil, allowing answering the questions about the dynamics of fluvial transport of dissolved and suspended solids, the chemical weathering processes and associated atmospheric/soil $\mathrm{CO}_{2}$ consumption, and the relationship between chemical weathering and soil erosion rates. The annual specific flux of total suspended solids and total dissolved solids were 49.59 and $60.97 \mathrm{t} / \mathrm{km}^{2} / \mathrm{yr}$. The chemical weathering process dominant in the Sorocaba River basin was the monosiallitization $(\mathrm{RE}=2.4)$, with an associated atmospheric/soil $\mathrm{CO}_{2}$ consumption of $2.3 \times 10^{5} \mathrm{~mol} / \mathrm{km}^{2} / \mathrm{yr}$. The chemical weathering and soil removal rates were 7.2 and $29.8 \mathrm{~m} / \mathrm{Myr}$, respectively, indicating a soil thickness reduction. Finally, the soil removal rate in the Sorocaba River basin is almost 3-fold higher than the Cenozoic soil removal rates, being this difference related to the current land use which increased the soil removal processes.
\end{abstract}

KEYWORDS: Fluvial geochemistry; disturbed watershed; water-rock interactions; rainwater and anthropogenic influences.

\section{INTRODUCTION}

Chemical weathering is typically a destructive process, which allows the development of new minerals from the weathering of primary minerals. In addition, water-rock interactions are responsible for the Earth's landscape, composition of surface and groundwater, producing the soils and buffering the composition of the atmosphere, being this process one of the main mechanisms of atmospheric $\mathrm{CO}_{2}$ removal and consequent deposition of carbonates $\mathrm{Ca}^{2+}$ and $\mathrm{Mg}^{2+}$ in oceans, playing an important role in moderating terrestrial climate (Gaillardet et al. 1999, Millot et al. 2002). Residual products are subject to other processes of the supergene cycle, such as erosion, transport, and sedimentation, which ultimately lead to continental denudation, with consequent flattening on the relief (Teixeira et al. 2000).

Pioneering studies to investigate the nature and composition of the dissolved and suspended load transported by rivers were performed in the 1960-70s (Barth 1961, Johnson et al. 1968, Gibbs 1970, Tardy 1971, Martin and Meybeck 1979). Since then, many studies have been carried out to assess chemical weathering and soil erosion rates using mass-balance models

\footnotetext{
${ }^{1}$ Universidade Estadual Paulista "Júlio de Mesquita Filho" - Rio Claro (SP), Brazil.E-mails: alefernandes1966@yahoo.com.br, ftomazini@rc.unesp.br, fabiano.tomazini@unesp.br

${ }^{2}$ Universidade de São Paulo - Piracicaba (SP), Brazil.

${ }^{*}$ Corresponding author.
}

adjusted to atmospheric and anthropogenic (mainly originating from domestic sewage and industrial and agricultural activities) contributions, once the total river fluxes integrate the contributions of these different sources (Probst 1986, 1992, Meybeck 1987, Lasaga et al. 1994, White and Blum 1995, Boeglin and Probst 1996, 1998, Boeglin et al. 1997, Gaillardet et al. 1999, Semhi et al. 2000, Millot et al. 2002, Meybeck et al. 2003, Walling and Fang 2003, Riebe et al. 2004, Chakrapani 2005, Weijden and Pacheco 2006, Louvat et al. 2008, Gurumurthy et al. 2012, Laraque et al. 2013, Li et al. 2014). The interest in assessing the chemical weathering and soil removal rates in watersheds under different geological and climatic setting also occurred in Brazil (Stallard and Edmond 1981, 1983, 1987, Moreira-Nordemann 1980, 1984, Mortatti et al. 1997, 2008, Gaillardet et al. 1997, Bortoletto Junior et al. 2002, Conceição and Bonotto 2003, 2004, Mortatti and Probst 2003, Bonotto et al. 2007, Sardinha et al. 2010, Fernandes et al. 2012, 2016a, Conceição et al. 2015, Couto Júnior et al. 2019, Spatti Júnior et al. 2019).

The state of São Paulo established 21 units of Water Resources Management (UGRHI), according to Law No. 7,663, published in December $30^{\text {th }}, 1991$ (São Paulo 1991). The Sorocaba River basin belongs to UGRHI-10 (Médio Tiête - Sorocaba), presents well-defined climatic seasonality (tropical climate) and a diverse geological and geomorphological context. Successive cycles of development and diversification of human activities have occurred since its occupation in the seventeenth century. Nowadays, this watershed covers 18 municipalities (1,212,376 inhabitants), an important industrial park, with over 1,850 enterprises and 
large agricultural areas (IBGE 2010). Approximately $65 \%$ of the demands for public supply in the Sorocaba River basin are supplied by Itupararanga Reservoir (IPT 2006). Despite its importance, few studies have been conducted in the Sorocaba River basin related to the rainwater chemical composition and annual atmospheric deposition (Conceição et al. 2011, 2013), the chemical weathering rates in the Upper Sorocaba River basin (Sardinha et al. 2010, Fernandes et al. 2016a), the water quality of the Itupararanga Reservoir (Pedrazzi et al. 2013, 2014), and the origin and flux of trace elements and isotopic composition of particulate organic matter in suspended sediment (Fernandes et al. 2012, 2016b).

Thus, this study aims to assess the chemical weathering and soil removal rates in the Sorocaba River basin, allowing answering the following questions:

- What are the dynamics of fluvial transport of dissolved and suspended solids?;

- What are the chemical weathering processes and associated atmospheric/soil $\mathrm{CO}_{2}$ consumption?;

- What is the relationship between the chemical weathering and soil removal rates?

\section{STUDY AREA}

The Sorocaba River basin is located in the southeastern portion of São Paulo State, Brazil, between latitudes 23 and $24^{\circ} \mathrm{S}$ and longitudes 47 and $48^{\circ} \mathrm{W}$, and occupies an area of $5,269 \mathrm{~km}^{2}$. Considered the most important tributary of the left bank of Tietê River, Sorocaba River travels $227 \mathrm{~km}$ before flowing into Tiete River, in Laranjal Paulista municipality (IPT 2006). This watershed is inserted into two main geomorphological units: Atlantic Plateau and Paulista Peripheral Depression (Ross 1996 - Fig. 1). The Atlantic Plateau presents metamorphic rocks belonging to the São Roque Group and Embu Complex, with associated granitic rocks (Godoy et al. 1996). The relief is comprised of hills shapes with convex tops and deep valleys with altitudes that range between 800 and 1,000 m a.s.l. and slope above 20\% (Ross 1996, Perrota et al. 2005). In the Paulista Peripheral Depression outcrop the sedimentary rocks belonging to the Parana Sedimentary Basin (Paleozoic-Mesozoic), i.e., Itararé Group (diamictic, sandstones, mudstones, and rhythmites), Guatá Group (siltstones and sandstones), and Passa Dois Group (siltstones, mudstones, and shales) (Conceição and Bonotto 2004, IPT 2006). The relief presents hills with tabular and large convex tops, prevailing altitudes between 600 and $700 \mathrm{~m}$ a.s.l. and slopes ranging from 5 to $10 \%$ (Ross 1996, Perrota et al. 2005).

The predominant soils in the study area are Red Argisol (49\%), Red Latosol (38\%), and Red-Yellow Latosol (9\%), according to the Brazilian soil classification (EMBRAPA 2013, Oliveira et al. 1999), corresponding to Ultisols and Oxisols in the USDA nomenclature (USDA 1999), respectively. Forests, fields, and Savanna characterized the original vegetation. Currently, with the agricultural occupation and the urbanization processes, land use is characterized by the predominance of the

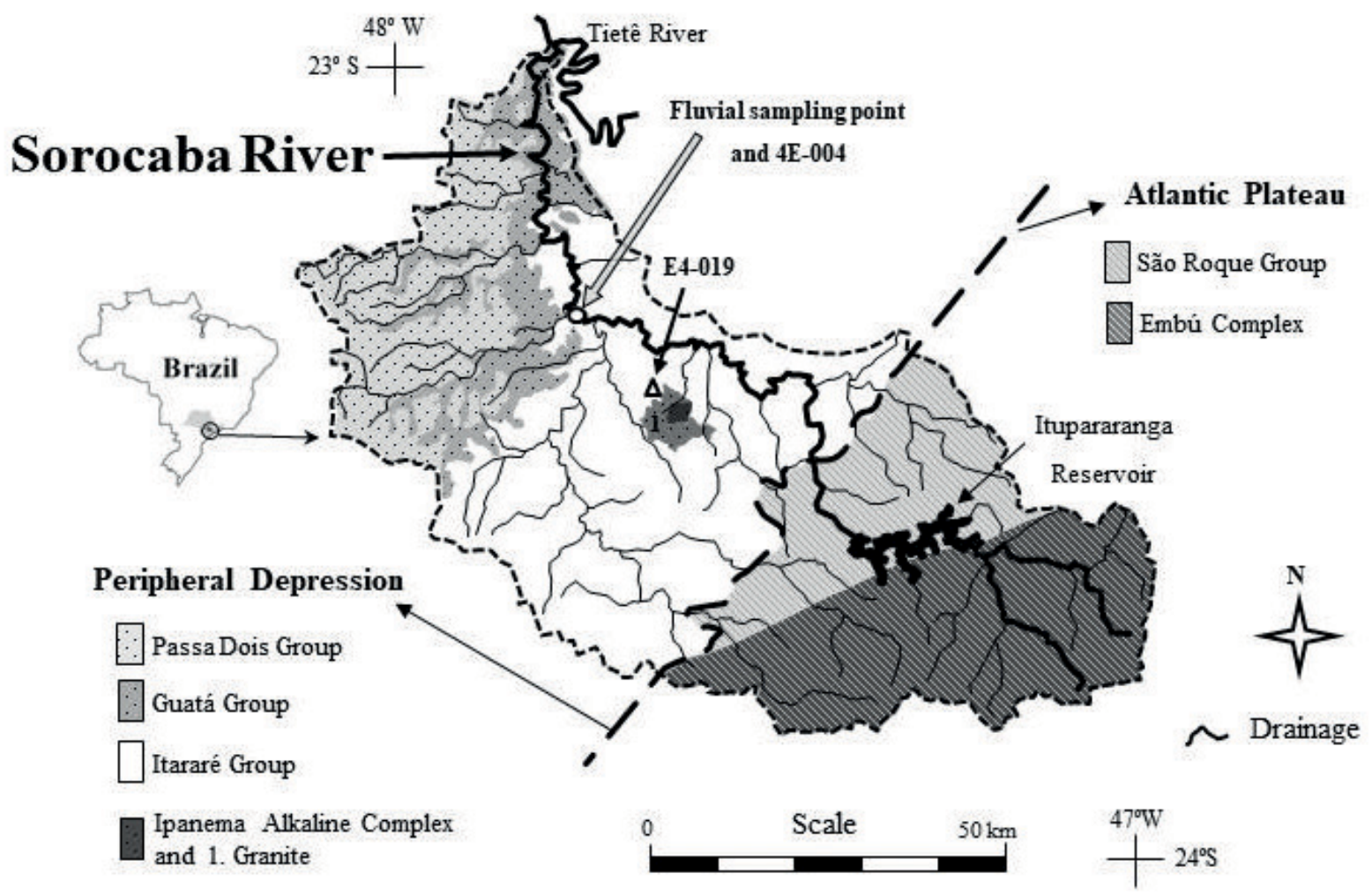

Figure 1. Geological map of Sorocaba River basin with location of the fluvial sampling point at the Tatuí municipality, and the pluviometric and fluviometric stations (E4-019 and 4E-004, respectively). 
pastures and fields (77\%), followed by areas with agricultural crops (14\%), reforestation areas (3\%), original vegetation cover (2\%), and urban areas (4\%) (IPT 2006).

The climate is Cwa type, according to the Köppen classification (Köppen 1948), characterized by the predominance of rainfall in summer and dryness in winter, with an average annual temperature of 18 to $22^{\circ} \mathrm{C}$ (IPT 2006). Figure $2 \mathrm{~A}$ shows the monthly averages of rainfall and discharge in the Sorocaba River basin from 1979 to 2008, calculated from the monthly historical data of the Pluviometric station E4-019 (2320'S, 47041'W) and the Fluviometric station 4E-004 (2319'S, 47046'W) (DAEE 2010), respectively. During this period, the average annual rainfall was $1,276 \mathrm{~mm}$, where January and August were the months with the highest and lowest rainfall values ( 236 and $35 \mathrm{~mm}$, respectively). In the same historical period, the average annual discharge was $53.8 \mathrm{~m}^{3} / \mathrm{s}$, with the highest monthly average in February $\left(98.3 \mathrm{~m}^{3} / \mathrm{s}\right)$ and lowest in August $\left(33.7 \mathrm{~m}^{3} / \mathrm{s}\right)$. Figure $2 \mathrm{~B}$ shows a significant positive linear correlation between the average monthly values of rainfall and discharge of these 30 years.

\section{MATERIALS AND METHODS}

\section{Sampling and analytical methods}

The river sampling point was established approximately $500 \mathrm{~m}$ upstream from the confluence of the Sorocaba and Tatuí rivers, in the municipality of Tatuí (Lat. 2319'09”S, Long. 47046'44"W), as can be seen in Figure 1, covering an area of $3,942 \mathrm{~km}^{2}$, i.e., $74.8 \%$ of the total area of the Sorocaba River basin, with a total population of $1,061,023$ inhabitants (IBGE 2010) and the urban sewage treatment percentage estimated at $17.5 \%$ (IPT 2006). This sampling point was chosen due to there being a fluviometric station installed (limnimetric ruler and an automatic limnigraph), managed by DAEE/ CTH, with daily discharge data since 1940 . These data were used to validate the discharge measurements performed during the sampling period.

Twelve fluvial water sample collections were carried out at the Sorocaba River, covering one complete hydrological cycle (Jun/2009 to Jun/2010). Sorocaba River waters (1,000 mL) were collected in each sampling at $1.5 \mathrm{~m}$ deep, using a single-stage punctual sampler. The samples were separated into two $500 \mathrm{~mL}$ aliquots, one crude and the other preserved with $0.1 \mathrm{~mL}$ of concentrated $\mathrm{H}_{2} \mathrm{SO}_{4}$. Both aliquots were stored in identified polyethylene bottles and kept at $4{ }^{\circ} \mathrm{C}$ until laboratory processing.

Discharge $(\mathrm{Q})$, hydrogenionic potential $(\mathrm{pH})$, electrical conductivity (EC), and temperature $(\mathrm{T})$ were characterized in the field using direct reading equipment. The discharge was represented by the product of the wet river channel cross-section area $\left(\mathrm{m}^{2}\right)$, obtained by bathymetry, and the average velocity of the water flow in this section $(\mathrm{m} / \mathrm{s})$ quantified using a Digital Micromolinete Global Water FP 101. The $\mathrm{pH}$ values were determined using a DM2 Digimed portable pHmeter, with a relative accuracy of $0.01 \%$ and calibrated with standard solutions DM-S1B ( $\mathrm{pH} 4.01$ ) and DM-S1A ( $\mathrm{pH}$ 6.86). In addition, $\mathrm{EC}$ and $\mathrm{T}$ were quantified using the Digimed DM3 sensor, with a resolution of $0.01 \mathrm{mS} / \mathrm{cm}$, relative accuracy of $0.05 \%$ and automatic temperature compensation, previously calibrated with conductivity standard solutions DM S6A $(1,412 \mathrm{mS} / \mathrm{cm}$ and DM S6B $(146.9 \mathrm{mS} / \mathrm{cm})$.

Crude fluvial water samples were filtered through cellulose membrane filters $(0.45 \mathrm{~mm})$, previously dried and weighed. These filtered samples were analyzed by ion chromatography Dionex ICS-90 equipped with analytical columns IonPac CS12A $4 \times 250 \mathrm{~mm}$ and IonPac AS14A $4 \times 250 \mathrm{~mm}$, for the quantification

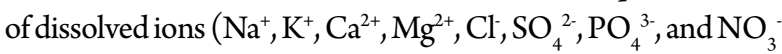
), with a detection limit of $0.001 \mathrm{mg} / \mathrm{L}$ (Dionex Corporation 2004) and quantification limit of $0.01 \mathrm{mg} / \mathrm{L}$ (Ribani et al. 2004). The $\mathrm{HCO}_{3}{ }^{-}$was represented by the alkalinity content and was quantified by the Gran method (Edmond 1970). The preserved fluvial water samples were filtered through a glass fiber membrane filter $(0.3-0.6 \mathrm{~mm})$ and used in the quantification of dissolved $\mathrm{Si}^{4+}$ concentration by optical emission spectrometry with inductively coupled argon plasma, ICP-OES Optima $3000 \mathrm{DV}$, with a detection limit of $0.02 \mathrm{mg} / \mathrm{L}$, and the result was expressed in terms of $\mathrm{SiO}_{2}$. The total dissolved solids (TDS) correspond to the sum of dissolved cations, anions and silica. The total suspended solids (TSS) was quantified by gravimetry (APHA 1999), considering the retained material in the cellulose membrane filter after drying in a stove at
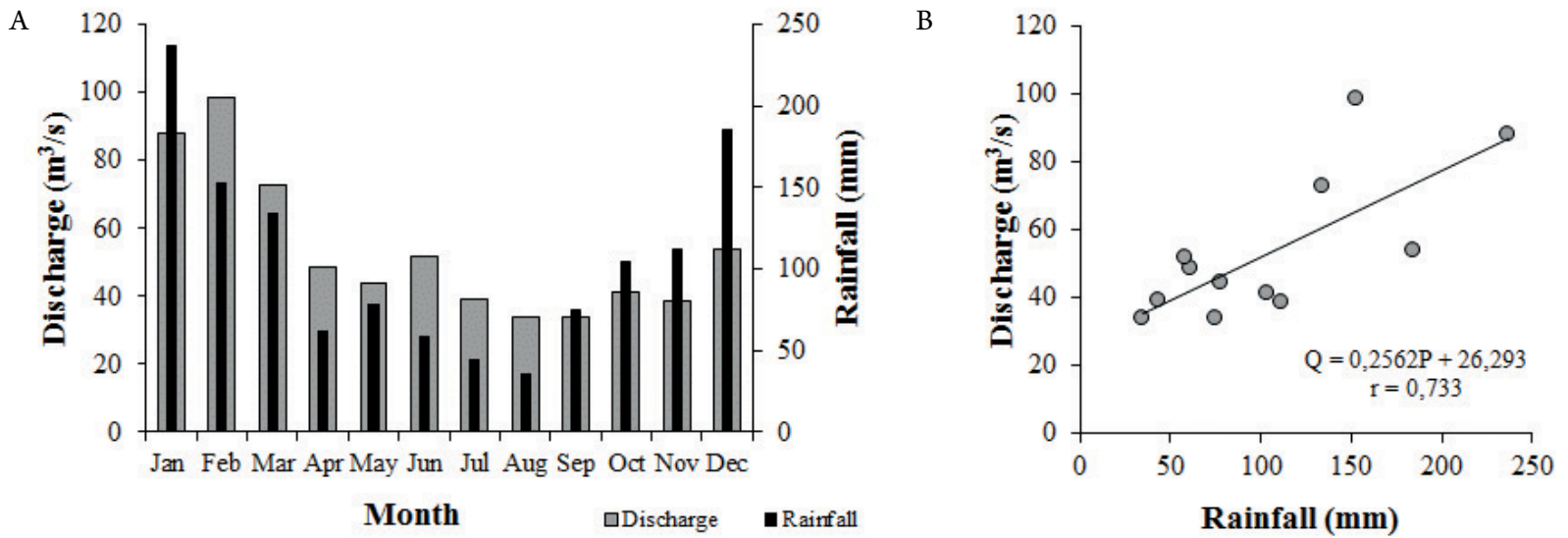

Figure 2. (A) Monthly average rainfall and discharge for a 30-year period (1979-2008) in the Sorocaba River basin, and (B) relationship between the monthly average rainfall and discharge for the same period. 
$60^{\circ} \mathrm{C}$ to constant weight. The analysis of the river water samples was performed at Stable Isotope Laboratory (dissolved ions, $\mathrm{HCO}_{3}^{-}$and TSS) and Analytical Chemistry Laboratory (dissolved silica), both located at CENA/USP.

\section{Theoretical background}

The fluvial fluxes $\left(F_{w^{\prime}}\right.$ in $\left.\mathrm{t} / \mathrm{km}^{2} / \mathrm{yr}\right)$ of dissolved chemical species, TDS and TSS related to chemical weathering and soil removal processes, were calculated using a mass balance model expressed in Equation 1 (White and Blum 1995), considering negligible the fluxes from the biomass change and derived from the ionic exchange sites in clay minerals.

$F_{W}=F_{\text {river }}-F_{\text {rainfall }}-F_{\text {anthropogenic }}$

In which:

$F_{\text {river }}=$ the measured river flux $\left(\mathrm{t} / \mathrm{km}^{2} / \mathrm{yr}\right)$

$F_{\text {rainfall }}=$ the atmospheric inputs $\left(\mathrm{t} / \mathrm{km}^{2} / \mathrm{yr}\right)$;

$F_{\text {anthropogenic }}=$ the anthropogenic influences $\left(\mathrm{t} / \mathrm{km}^{2} / \mathrm{yr}\right)$.

The $R_{\mathrm{E}}$ index can be used to determine the predominant process of chemical weathering of rocks in a drainage basin. Initially proposed by Tardy (1971), this index is equivalent to the molecular ratio $\left(\mathrm{SiO}_{2}\right) /\left(\mathrm{Al}_{2} \mathrm{O}_{3}\right)$ of secondary minerals neoformation within the soil profile. Boeglin and Probst (1998) modified the $R_{\mathrm{E}}$ index, being expressed by the molar ratio of chemical dissolved species in the surface waters (Eq. 2).

$R_{E}=\frac{3 \mathrm{~K}+3 \mathrm{Na}+2 \mathrm{Ca}+1.25 \mathrm{Mg}-\mathrm{SiO}_{2}}{0.5 \mathrm{~K}+0.5 \mathrm{Na}+\mathrm{Ca}+0.75 \mathrm{Mg}}$

The atmospheric/soil $\mathrm{CO}_{2}$ consumption during chemical weathering processes $\left(F_{\mathrm{CO} 2}-\mathrm{in} \mathrm{mol} / \mathrm{km}^{2} / \mathrm{yr}\right)$ was estimated by the sum of corrected fluxes of $\mathrm{Na}^{+}, \mathrm{K}^{+}, \mathrm{Ca}^{2+}$, and $\mathrm{Mg}^{2+}\left(F_{\text {(ion) }}\right.$
${ }_{\text {sil }}$ - in $\mathrm{mol} / \mathrm{km}^{2} / \mathrm{yr}$ ), according to Equation 3 (Gaillardet et al. 1999, Gurumurthy et al. 2012).

$F_{\mathrm{CO} 2}=F_{\mathrm{Nasil}}+F_{\mathrm{Ksil}}+2 F_{\text {Casil }}+2 F_{\mathrm{Mgsil}}$

The chemical weathering of rocks ( $I Q-$ in $\mathrm{t} / \mathrm{km}^{2} / \mathrm{yr}$ ) can be estimated through the sum of the corrected annual fluvial flux of $\mathrm{Na}^{+}, \mathrm{K}^{+}, \mathrm{Ca}^{2+}, \mathrm{Mg}^{2+}$, and $\mathrm{SiO}_{2}\left(F_{\mathrm{W}}(\right.$ ion $)$ - in $\left.\mathrm{t} / \mathrm{km}^{2} / \mathrm{yr}\right)$, i.e., after correction of atmospheric inputs and anthropogenic contributions, according to Equation 5 (Probst 1992). The ratio among the $I Q$ and the average density of rocks for the watershed represent the chemical weathering rate ( $W q$ - in $\mathrm{m} /$ Myr), as expressed in Equation 5.

$I Q=F_{W}\left(\mathrm{Na}^{+}\right)+F_{W}\left(\mathrm{~K}^{+}\right)+F_{W}\left(\mathrm{Ca}^{2+}\right)+F_{W}\left(\mathrm{Mg}^{2+}\right)+F_{W}\left(\mathrm{SiO}_{2}\right)$

$W_{q}=\frac{I Q}{\rho}$

The soil removal rates $\left(W_{\mathrm{m}}\right.$ in $\left.\mathrm{m} / \mathrm{Myr}\right)$ can be calculated through Equation 5; however, the use of corrected TSS annual flux $\left(\mathrm{t} / \mathrm{km}^{2} / \mathrm{yr}\right)$ and the average soil density $\left(\mathrm{g} / \mathrm{cm}^{3}\right)$ is necessary instead of $I Q$ and average density of rocks, respectively (Mortatti et al. 1997, Boeglin and Probst 1998).

\section{RESULTS}

Table 1 shows the results of $\mathrm{Q}, \mathrm{pH}, \mathrm{EC}, \mathrm{T}$ and the concentrations of dissolved ions and $\mathrm{SiO}_{2}, \mathrm{TDS}$, and TSS, with their respective discharge weighted average for the study period.

The discharge showed seasonal variation in consonance with the historical data of the monthly average (Fig. 2A), with the highest value obtained in $\operatorname{Jan} / 2010\left(230.40 \mathrm{~m}^{3} / \mathrm{s}\right)$ and the lowest in Jun/2009 $\left(28.77 \mathrm{~m}^{3} / \mathrm{s}\right)$. Despite the similar seasonality,

Table 1. Physical and chemical parameters for the Sorocaba River surface waters.

\begin{tabular}{|c|c|c|c|c|c|c|c|c|c|c|c|c|c|c|}
\hline \multirow{2}{*}{ Parameter } & \multirow{2}{*}{ Unit } & \multicolumn{12}{|c|}{ Sampling date } & \multirow{2}{*}{$\mathbf{C}_{\text {wAV }}$} \\
\hline & & Jun/09 & Jul/09 & Aug/09 & Sep/09 & Nov/09 & Dec/09 & Jan/10 & Feb/10 & Mar/10 & Apr $/ 10$ & May/10 & Jun/10 & \\
\hline Q & $\mathrm{m}^{3} / \mathrm{s}$ & 28.77 & 32.60 & 81.35 & 67.01 & 110.03 & 228.58 & 230.49 & 118.64 & 98.56 & 71.79 & 48.85 & 31.64 & 95.69 \\
\hline $\mathrm{pH}$ & & 6.8 & 6.9 & 6.9 & 6.9 & 6.7 & 6.5 & 6.6 & 6.8 & 6.8 & 6.9 & 6.8 & 6.9 & 6.7 \\
\hline $\mathrm{EC}$ & $\mathrm{mS} / \mathrm{cm}$ & 136.9 & 141.8 & 108.6 & 110.9 & 82.2 & 70.9 & 73.7 & 98.1 & 89.5 & 99.0 & 115.0 & 128.0 & 104.6 \\
\hline $\mathrm{T}$ & ${ }^{\circ} \mathrm{C}$ & 16.7 & 17.0 & 16.5 & 19.5 & 26.3 & 26.2 & 27.5 & 25.0 & 26.8 & 25.5 & 22.0 & 20.3 & 22.4 \\
\hline $\mathrm{SiO}_{2}$ & $\mathrm{mg} / \mathrm{L}$ & 34.00 & 28.00 & 13.72 & 13.66 & 14.00 & 9.91 & 9.53 & 11.70 & 11.58 & 12.07 & 16.00 & 28.00 & 13.05 \\
\hline $\mathrm{Ca}^{2+}$ & $\mathrm{mg} / \mathrm{L}$ & 17.92 & 16.90 & 9.20 & 10.40 & 9.00 & 5.69 & 6.80 & 10.40 & 11.70 & 13.41 & 13.08 & 15.00 & 9.43 \\
\hline $\mathrm{Mg}^{2+}$ & $\mathrm{mg} / \mathrm{L}$ & 1.32 & 1.02 & 0.90 & 0.97 & 0.86 & 0.80 & 0.87 & 0.92 & 1.00 & 1.10 & 1.10 & 1.40 & 0.93 \\
\hline $\mathrm{Na}^{+}$ & $\mathrm{mg} / \mathrm{L}$ & 19.15 & 15.92 & 10.59 & 11.41 & 6.38 & 5.64 & 5.61 & 7.22 & 8.03 & 8.65 & 10.94 & 13.82 & 8.03 \\
\hline $\mathrm{K}^{+}$ & $\mathrm{mg} / \mathrm{L}$ & 2.26 & 1.90 & 1.70 & 1.83 & 1.65 & 1.47 & 1.70 & 1.75 & 1.90 & 2.00 & 2.10 & 2.30 & 1.75 \\
\hline $\mathrm{HCO}_{3}^{-}$ & $\mathrm{mg} / \mathrm{L}$ & 51.31 & 45.05 & 36.03 & 38.59 & 35.21 & 25.77 & 30.26 & 38.00 & 36.20 & 37.99 & 39.86 & 43.41 & 34.25 \\
\hline $\mathrm{Cl}^{-}$ & $\mathrm{mg} / \mathrm{L}$ & 18.90 & 15.20 & 7.86 & 8.62 & 4.26 & 3.63 & 4.40 & 5.48 & 6.28 & 7.50 & 8.64 & 10.75 & 6.22 \\
\hline $\mathrm{SO}_{4}^{2-}$ & $\mathrm{mg} / \mathrm{L}$ & 7.74 & 6.56 & 4.47 & 4.82 & 4.08 & 2.71 & 2.37 & 2.72 & 4.40 & 5.28 & 5.99 & 9.25 & 3.88 \\
\hline $\mathrm{NO}_{3}^{-}$ & $\mathrm{mg} / \mathrm{L}$ & 4.82 & 3.10 & 2.06 & 2.29 & 1.53 & 0.66 & 0.87 & 1.45 & 3.40 & 4.00 & 5.38 & 5.61 & 2.02 \\
\hline $\mathrm{PO}_{4}^{3-}$ & $\mathrm{mg} / \mathrm{L}$ & 0.13 & 0.16 & 0.07 & 0.04 & 0.07 & 0.02 & 0.03 & 0.05 & 0.16 & 0.16 & 0.19 & 0.21 & 0.07 \\
\hline TDS & $\mathrm{mg} / \mathrm{L}$ & 157.55 & 133.81 & 86.61 & 92.63 & 77.05 & 56.29 & 62.45 & 79.69 & 84.64 & 92.16 & 103.28 & 129.74 & 79.64 \\
\hline TSS & $\mathrm{mg} / \mathrm{L}$ & 19.50 & 31.00 & 70.33 & 50.83 & 105.33 & 74.00 & 66.33 & 25.83 & 66.67 & 41.67 & 18.33 & 11.83 & 59.56 \\
\hline
\end{tabular}

$\mathrm{C}_{\mathrm{WAV}}$ : weighted average element/compound concentration for the study period; Q: discharge; EC: electrical conductivity; T: temperature; TDS: total dissolved solids; TSS: total suspended solids. 
the average discharge for the study period $\left(95.69 \mathrm{~m}^{3} / \mathrm{s}\right)$ was 1.8 times higher than the historical annual average for the period of $1979-2008\left(53.8 \mathrm{~m}^{3} / \mathrm{s}\right)$. This is justified by the fact that the rainfall in the study period $(2,101 \mathrm{~mm})$ was higher than the historical average $(1,276 \mathrm{~mm})$, with a direct impact on the discharge values. During the historical period, a similar occurrence was observed only in 1983, with an annual rainfall of 2,054.0 mm and average discharge of $143.49 \mathrm{~m}^{3} / \mathrm{s}$.

The Sorocaba River waters presented a $\mathrm{pH}$ close to neutral, ranging from 6.5 to 6.9 . The $\mathrm{EC}$ showed a significant seasonal variation (annual average of $104.6 \mathrm{mS} / \mathrm{cm}$ ), with values below $74 \mathrm{mS} / \mathrm{cm}$ in the months of highest rainfall and discharge, and values above $135 \mathrm{mS} / \mathrm{cm}$ in Jun and Jul/2009. During the dry season (May to October), EC values were higher than the expected limit for natural waters, i.e., $100 \mathrm{mS} / \mathrm{cm}$ (Hermes and Silva 2004). The $\mathrm{T}$ followed the seasonal variation, with the lower values in winter $\left(16.5^{\circ} \mathrm{C}\right.$ in $\left.\mathrm{Aug} / 2009\right)$ and higher in summer $\left(27.5^{\circ} \mathrm{C}\right.$ in Jan/2010).

The concentration of [TSS] was directly related to the discharge (Fig. 3A). According to Probst (1986), for most world rivers the model obtained for the relationship between $[\mathrm{TSS}]$ and $\mathrm{Q}\left([\mathrm{TSS}]=a \cdot \mathrm{Q}^{\mathrm{b}}\right)$ presents positive $b$ exponent with values between 1 and 2, indicating that the increase in [TSS] is a function of the discharge increase. This exponent in the model established for the Sorocaba River was 0.7039, indicating that the [TSS] was also influenced by rainfall. This influence is highlighted in the November and December 2009, when the fluvial water sampling was performed after two days of significant precipitation, with accumulated volumes of 45.8 and $25.9 \mathrm{~mm}$, respectively.

On the other hand, the relationship between [TDS] and discharge was inverse and significant (Fig. 3B), which characterizes the dilution process with increasing discharge. Among the dissolved chemical species that composes the TDS, evaluable on a molar basis of $C_{\text {WAV }}$ the anionic predominance of $\mathrm{HCO}_{3}^{-}(33.1 \%)$ was verified, followed by $\mathrm{Cl}, \mathrm{SO}_{4}{ }^{2-}, \mathrm{NO}_{3}$, and $\mathrm{PO}_{4}^{3}$, while for the cations the greatest participation was $\mathrm{Na}^{+}$, with $20.6 \%$, followed by $\mathrm{Ca}^{2+}, \mathrm{Mg}^{2+}$, and $\mathrm{K}^{+}$, respectively, and the $\mathrm{SiO}_{2}$ represented $12.8 \%$ of the TDS. The relationship "sum of cation vs. sum of anion" (Probst 1992), in meq/L, indicated a deficit of anionic charge in the charge balance (Fig. 3C). It can be attributed to the presence of dissolved organic anions not counted in this study, such as dissolved organic carbon (Probst et al. 1992, Boeglin and Probst 1996, Laraque et al. 2013).

\section{DISCUSSION}

\section{Dynamics of fluvial transport in the Sorocaba River basin}

The fluvial fluxes integrate the contributions of the chemical weathering and soil removal processes that occur in natural watersheds. However, nowadays it is also necessary to consider the atmospheric inputs and anthropogenic influences in the fluvial dynamics (Stallard and Edmond 1981, Mortatti et al. 1997, Semhi et al. 2000, Bortoletto Junior et al. 2002, Conceição and Bonotto 2004, Weijden and Pacheco 2006, Mortatti et al. 2008, Conceição et al. 2010, Hissler et al. 2015, 2016).

The $F_{\text {river }}$ of dissolved chemical species, TDS and TSS were quantified in the specific transport form, the result of the product between $C_{\text {WAV }}$ and average discharge of the study period weighted by surface of study area, according to the stochastic methodology proposed by Probst (1992). $F_{\text {rainfall }}$ was represented by the specific input of solute, obtained from the total precipitation in the study period $(2,101 \mathrm{~mm})$ and the average concentration of dissolved chemical species obtained by Fernandes (2012).

The $F_{\text {anthropogenic }}$ for dissolved chemical species, TDS and TSS were obtained using secondary data, despite the uncertainties associated with these data regarding the reality of the studied basin. In relation to dissolved load, it was considering the per capita values of the dissolved chemical species present in untreated domestic effluents discharged directly in the river $(\mathrm{g} / \mathrm{hab} /$ day) established by Mortatti et al. $(2008,2012)$ for the Médio Tietê basin $\left(\mathrm{SiO}_{2}=0.84\right.$, $\mathrm{Ca}^{2+}=7.50, \mathrm{Mg}^{2+}=1.3, \mathrm{Na}^{+}=13.1, \mathrm{~K}^{+}=2.6, \mathrm{HCO}_{3}{ }^{-}=$ $42.0, \mathrm{Cl}^{-}=7.1$, and $\left.\mathrm{SO}_{4}{ }^{2-}=12.5\right)$, and the total population upstream of the sampling point $(1,061,023$ inhabitants). The anthropogenic contribution of $\mathrm{SiO}_{2}$ was considered negligible, such as reported in other studies (Mortatti et al. 2008, 2012). On the other hand, the $F_{\text {anthropogenic }}$ associated to suspended sediment load was represented by the per capita TSS load contained in untreated urban sewage $(0.022 \mathrm{~kg} / \mathrm{hab} / \mathrm{day})$, obtained from average production of untreated urban sewage $(100 \mathrm{~L} / \mathrm{hab} /$ day $)$ and respective TSS average concentration $(220 \mathrm{mg} / \mathrm{L})$, both global references data published by Tchobanoglous and Burton (1991), the total population upstream of the sampling point and the respective percentage of urban sewage treatment (17.5\%) (IBGE 2010).
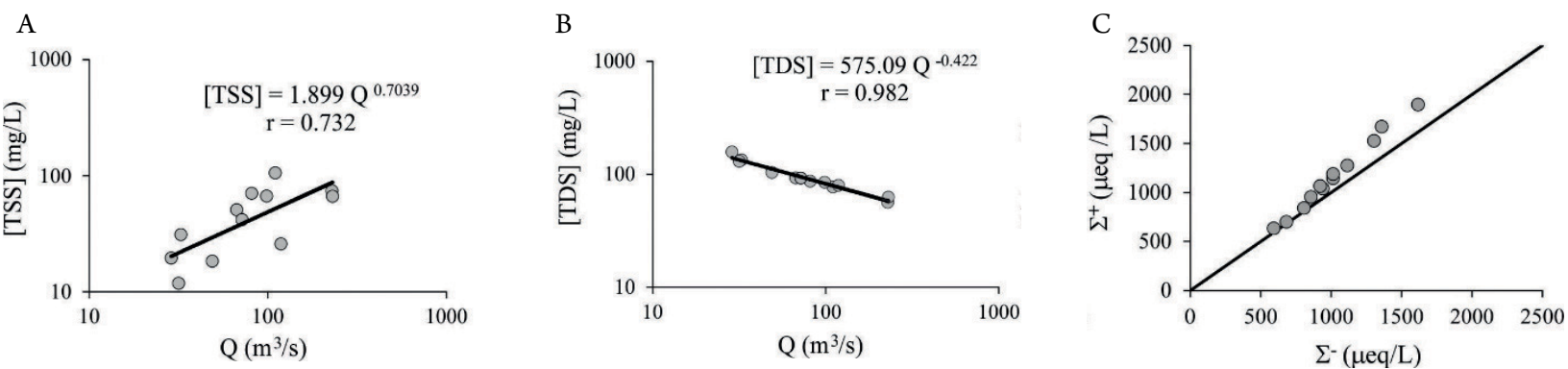

Figure 3. Relationships (A) between discharge and [TSS] and (B) between discharge and [TDS], (C) and charge balance in the Sorocaba River in the study period, with $\mathrm{S}^{+}$and $S$ corresponding to total dissolved cations and anions, respectively. 
The fluxes of cations, anions, silica, TDS, and TSS in the Sorocaba River basin are shown in Table 2. The total fluvial flux of TDS was 33\% higher than that observed to TSS flux. Among the dissolved chemical species, the $\mathrm{HCO}_{3}$ presented the highest fluvial flux, corresponding to $43 \%$ of TDS, followed by $\mathrm{SiO}_{2}$ (16.4\%), $\mathrm{Ca}^{2+}(11.8 \%), \mathrm{Na}^{+}(10.1 \%)$, and $\mathrm{Cl}^{-}(7.8 \%)$, while the fluvial flux presented by $\mathrm{SO}_{4}^{2-}, \mathrm{NO}_{3}$; $\mathrm{K}^{+}, \mathrm{Mg}^{2+}$ and $\mathrm{PO}_{4}^{3-}$ were lower than $5 \mathrm{t} / \mathrm{km}^{2} / \mathrm{yr}$ and together represented the remaining $10.9 \%$ of TDS. The atmospheric inputs account for $17.3 \%$ of the total specific flux of TDS in the Sorocaba River. Regarding the anthropogenic inputs, there was a higher contribution to the dissolved load (ca. $14 \%$ of the fluvial TDS) than to the suspended solids load (ca. $4 \%$ of the fluvial TSS).

Assuming that the suspended load represents approximately $90 \%$ of the total sediment river flux (Walling and Fang 2003), the specific flux of the total suspended solids exported by the Sorocaba River was estimated at $45.59 \mathrm{t} /$ $\mathrm{km}^{2} / \mathrm{yr}$. After correction of the anthropogenic contributions, the specific flux related to the soil removal $\left(F_{w}\right)$ was $43.81 \mathrm{t} / \mathrm{km}^{2} / \mathrm{yr}$. According to the classification proposed by Meybeck et al. (2003) for the world's rivers, from very low to extremely high, the soil removal in the Sorocaba River basin was considered as medium-specific sediment flux (range from 18.25 to $73 \mathrm{t} / \mathrm{km}^{2} / \mathrm{yr}$ ).

\section{Chemical weathering processes and atmospheric/soil $\mathrm{CO}_{2}$ consumption}

The weathering process is characterized according to the classification proposed by Pedró (1966), where $R_{\mathrm{E}} \approx 0$ characterizes the total hydrolysis process called allitization, with only aluminum and iron fixed as insoluble hydroxides; when $R_{\mathrm{E}} \approx 2$, the process is called partial hydrolysis with monosiallitization, occurring the kaolinite formation; and to $R_{\mathrm{E}} \approx 4$ the predominant process is the partial hydrolysis with bisiallitization and is related to the formation of mineral $2: 1$, such as montmorillonite.

The predominant process of chemical weathering of rocks in the Sorocaba River basin, was determined using the $R_{\mathrm{E}}$ index (Eq. 2) and corresponded to 2.4, value that characterizes the predominance of partial hydrolysis with a tendency to monosiallitization, i.e., to the kaolinite stability domain, similar to that observed in the Amazonas River basin (Mortatti and Probst 2003). However, in two watersheds (Tietê and Piracicaba river basins) located in the same region of the Sorocaba River, a different situation was verified, i.e., a tendency to the bisiallitization domain, probably due to extensive agricultural areas with a high degree of soil tillage, fact that may influence the remobilization of major ions instead of silica (Bortoletto Junior 2004).

According to Conceição and Bonotto (2004) and Fernandes et al. (2016a), the main minerals found in the igneous and metamorphic rocks of the Sorocaba River basin are biotite $\left(\mathrm{K}(\mathrm{Mg}, \mathrm{Fe})_{3}\left(\mathrm{Si}_{3} \mathrm{Al}\right) \mathrm{O}_{10}(\mathrm{OH})_{2}\right)$, muscovite $\left(\mathrm{KAl}_{2}\left(\mathrm{Si}_{3} \mathrm{Al}\right)\right.$ $\left.\mathrm{O}_{10}(\mathrm{OH})_{2}\right)$, sillimanite $\left(\mathrm{Al}_{2} \mathrm{SiO}_{5}\right)$, quartz $\left(\mathrm{SiO}_{2}\right)$, microcline $\left(\mathrm{KAlSi}_{3} \mathrm{O}_{8}\right)$, oligoclase $\left((\mathrm{Na}, \mathrm{Ca})(\mathrm{Si}, \mathrm{Al})_{4} \mathrm{O}_{8}\right)$, and hornblende $\left(\mathrm{Ca}_{2} \mathrm{Na}(\mathrm{Mg}, \mathrm{Fe})_{4}(\mathrm{Al}, \mathrm{Fe}, \mathrm{Ti}) \mathrm{AlSi}_{8} \mathrm{AlO}_{22}(\mathrm{OH})_{2}\right)$. For sedimentary rocks, quartz, albite (NaAlSi3O 8$)$, microcline, kaolinite $\left(\mathrm{Al}_{2} \mathrm{Si}_{2} \mathrm{O}_{5}(\mathrm{OH})\right)$, and illite $\left(\mathrm{K}_{0.9} \mathrm{Al}_{2} \mathrm{Si}_{4} \mathrm{O}_{10}(\mathrm{OH})_{2}\right)$ were highlighted. Theoretically, the weathering reactions involving the mineral rock of the Sorocaba River basin indicate that the $\mathrm{Na}^{+}$ has its origin in the hydrolysis of albite, hornblende and plagioclase; $\mathrm{K}^{+}$ions are derived from the hydrolysis of muscovite, microcline, biotite and illite; the $\mathrm{Ca}^{2+}$ can be attributed to the hydrolysis of hornblende and plagioclase; and $\mathrm{Mg}^{2+}$ can be released by the hydrolysis of hornblende and biotite. In addition, the Sorocaba River basin does not contain volumetrically significant $\mathrm{Cl}^{-}, \mathrm{NO}_{3}^{-}, \mathrm{PO}_{4}^{3-}$ or $\mathrm{SO}_{4}^{2-}$ bearing minerals. Therefore, only small inputs of these anions are expected in the rivers due to water-rock interactions. Quartz and kaolinite are not weathered and remain in the soil profile, as well as the supergene minerals, i.e., kaolinite, goethite $(\mathrm{FeOOH})$, and rutile $\left(\mathrm{TiO}_{2}\right)$.

The atmospheric/soil $\mathrm{CO}_{2}$ consumption during the chemical weathering processes in the Sorocaba River basin was obtained using Equation 3 and corresponded to $2.3 \times 10^{5} \mathrm{~mol} / \mathrm{km}^{2} / \mathrm{yr}$. This value was lower than that observed in the Tietê River basin $\left(3.8 \times 10^{5} \mathrm{~mol} / \mathrm{km}^{2} / \mathrm{yr}\right.$, Bortoletto Junior 2004). However, it was higher than other Brazilian watersheds, such as the Amazonas Basin (0.3 $\times$ $10^{5} \mathrm{~mol} / \mathrm{km}^{2} / \mathrm{yr}$, Mortatti and Probst 2003) and Jamari and Jiparana basins $\left(0.8 \times 10^{5}\right.$ and $1.4 \times 10^{5} \mathrm{~mol} / \mathrm{km}^{2} / \mathrm{yr}$, respectively, Mortatti et al. 1992) in northern region, or in the Paraná Basin $\left(0.9 \times 10^{5} \mathrm{~mol} / \mathrm{km}^{2} / \mathrm{yr}\right.$, Gaillardet et al. 1999) and Piracicaba Basin $\left(1.4 \times 10^{5} \mathrm{~mol} / \mathrm{km}^{2} / \mathrm{yr}\right.$, Bortoletto Junior 2004), both in the Southeastern Brazilian region.

\section{Chemical weathering and soil removal rates}

The IQ value in the Sorocaba River basin, obtained using Equation 4 and the data of Table 2, corresponded to a flux of $19.1 \mathrm{t} / \mathrm{km}^{2} / \mathrm{yr}$, representing $31.4 \%$ of TDS flux at the river. The Amazonas and Tietê River basins showed higher fluxes (IQ) than that observed for the Sorocaba River

Table 2. The annual flux ( $\left.\mathrm{t} / \mathrm{km}^{2} / \mathrm{yr}\right)$ of total suspended solids (TSS), total dissolved solids (TDS), dissolved silica, cations and anions in the Sorocaba River basin.

\begin{tabular}{lcccccccccccc}
\hline Species & TSS & TDS & $\mathbf{S i O}_{2}$ & $\mathbf{C a}^{2+}$ & $\mathbf{M g}^{2+}$ & $\mathbf{N a}^{+}$ & $\mathbf{K}^{+}$ & $\mathbf{H C O}_{3}{ }^{-}$ & $\mathbf{C l}^{-}$ & $\mathbf{S O}_{4}{ }^{2-}$ & $\mathbf{N O}_{3}{ }^{-}$ & $\mathbf{P O}_{4}{ }^{3-}$ \\
\hline $\mathrm{F}_{\text {river }}$ & 45.59 & 60.97 & 9.99 & 7.22 & 0.71 & 6.15 & 1.34 & 26.22 & 4.76 & 2.97 & 1.54 & 0.06 \\
$\mathrm{~F}_{\text {rainfall }}$ & --- & 10.57 & --- & 2.99 & 0.12 & 0.40 & 0.28 & 3.60 & 0.71 & 1.24 & 1.18 & 0.05 \\
$\mathrm{~F}_{\text {antropogenic }}$ & 1.78 & 8.54 & 0.08 & 0.74 & 0.13 & 1.29 & 0.26 & 4.13 & 0.70 & 1.23 &.-- & --- \\
$\mathrm{F}_{\mathrm{w}}$ & 43.81 & 41.85 & 9.91 & 3.49 & 0.47 & 4.46 & 0.80 & 18.49 & 3.35 & 0.50 & 0.36 & 0.01 \\
\hline
\end{tabular}

*Data reported in Fernandes (2012). 
basin, with 32.2 e $41.4 \mathrm{t} / \mathrm{km}^{2} / \mathrm{yr}$, respectively (Mortatti and Probst 2003, Bortoletto Junior 2004). The chemical weathering rate $(W q)$ for the Sorocaba River basin was calculated using Equation 5 and the regional value of the mean density of rocks $\left(2.65 \mathrm{~g} / \mathrm{cm}^{3}-\right.$ Brasil 1983) and corresponded to $7.2 \mathrm{~m} / \mathrm{Myr}$. This rate was 22 and 54\% higher than those obtained for the Tietê ( $5.9 \mathrm{~m} / \mathrm{Myr}$ ) and Piracicaba ( $4.7 \mathrm{~m} / \mathrm{Myr}$ ) river basins, respectively (Bortoletto Junior 2004).

The soil removal rate in the Sorocaba River basin was $29.8 \mathrm{~m} / \mathrm{Myr}$, considering that the average soil density is 1.47 $\mathrm{g} / \mathrm{cm}^{3}$ (Fernandes et al. 2012). This rate was lower than that observed in the Amazonas River basin (123 m/Myr, Mortatti and Probst 2003) and higher than that in the Jamari and Jiparaná river basins $(6.5 \mathrm{~m} / \mathrm{Myr}$ in both basins, Mortatti et al. 1992). The Tietê and Piracicaba river basins, located in the same geographical region as the Sorocaba River, presented higher rates when compared to those obtained in this study, i.e., 42.6 and $37.0 \mathrm{~m} / \mathrm{Myr}$, respectively (Bortoletto Junior 2004). Considering the chemical weathering and soil removal rates in the Sorocaba River basin (7.2 and $29.8 \mathrm{~m}$ / Myr, respectively), in the present climatic setting, there is a soil thickness reduction.

The cooling/denudation crustal rates quantified using apatite fission track (AFT), apatite (U-Th)/He (AHe) and in situ cosmogenic ${ }^{10} \mathrm{Be}$ could be used to compare the present soil removal rates obtained by a fluvial mass-balance with the Cenozoic soil removal rates. Values of past denudation obtained in southeast Brazil ranging from 8.8 to $15.7 \mathrm{~m} / \mathrm{Myr}$, using in situ cosmogenic ${ }^{10} \mathrm{Be}$ (Cherem et al. 2012). Hackspacher et al. (2004) used AFT ages to indicate a cooling/denudation rate of $11 \mathrm{~m} / \mathrm{Myr}$ at the boundary between the Paraná Sedimentary Basin and the basement rocks. The soil removal rate in the Sorocaba River basin ( $29.8 \mathrm{~m} / \mathrm{Myr}$ ) is almost 3-fold higher than the estimates of Cenozoic denudation reported Cherem et al. (2012) and Hackspacher et al. (2004). This difference can be explained by the present land use in the Sorocaba River basin, where the replacement of the original vegetation by agricultural and livestock activities increased the erosion processes and, consequently, the present denudation rates, even though the study region has remained roughly in the same latitude during the drift to west of South America, since the time of the separation of continents and the basalt eruptions of the Serra Geral Formation.

Couto Júnior et al. (2019) evaluated three different scenarios from land use changes and how they have affected soil loss in a watershed located in the PPD, using the USLE model. Similar to Sorocaba River basin, the main types of soils occurring in the studied area were Ultisol and Oxisol. The authors verified a similar soil removal rate, it was almost 3-fold higher than the long-term denudation rates suggested by the literature for the Peripheral Depression, and reinforced that the increase in the denudation rate is mainly related to land use/land cover changes than to the soil type present in the studied area.

\section{CONCLUSION}

This study aimed to evaluate the chemical weathering of rocks and soil removal processes that occur in the Sorocaba River basin and allowed a better understanding of the dynamics of fluvial transport of dissolved and suspended solids, of the chemical weathering processes and the atmospheric/soil $\mathrm{CO}_{2}$ consumption and of the relationship between chemical weathering and soil removal rates. The TSS concentration was directly related to the discharge and influenced by rainfall, with higher concentrations recorded after rainfall events. However, the TDS concentration showed dilution behavior in a wet period. The annual specific flux of TDS was $60.97 \mathrm{t} / \mathrm{km}^{2} / \mathrm{yr}$, but after the atmospheric inputs and anthropogenic contributions (ca. 17 and 14\%, respectively) this value was corrected to $41.85 \mathrm{t} / \mathrm{km}^{2} / \mathrm{yr}$ and represents the fluvial flux related to the chemical weathering of rocks. The total annual specific flux of TSS was $45.59 \mathrm{t} / \mathrm{km}^{2} / \mathrm{yr}$, with a small portion derived from the anthropogenic contributions (ca. 4\%). The chemical weathering process showed a tendency to monosiallitization $\left(\mathrm{R}_{\mathrm{E}}=2.4\right)$, with an atmospheric/soil $\mathrm{CO}_{2}$ consumption rate of $2.3 \times 10^{5} \mathrm{~mol} / \mathrm{km}^{2} / \mathrm{yr}$. The chemical weathering and soil removal rates were 7.2 and $29.8 \mathrm{~m} / \mathrm{Myr}$, respectively, indicating a soil thickness reduction. The present soil removal rate in the Sorocaba River basin was almost 3-fold higher than the Cenozoic soil removal rates, reinforcing that the human-landscape systems are complex and affect the natural denudation rates, and, consequently, the present landscape evolution in the State of São Paulo.

\section{ACKNOWLEDGMENTS}

The authors are grateful to Fundação de Amparo à Pesquisa do Estado de São Paulo (FAPESP) (Process No. 08/57104-4 and 08/09369-9) and Conselho Nacional de Desenvolvimento Científico e Tecnológico (CNPq) (Process No. 134169/2009-3), for financial support. The authors would also like the Stable Isotope Laboratory of the Center for Nuclear Energy in Agriculture (LIE-CENA/USP), São Paulo, Brazil, for the research infrastructure. A. M. Fernandes is also grateful to the Graduate Program of the Faculty of Civil Engineering of UNESP Bauru, for the Postdoctoral grant. Specially, Dr. Claudio Riccomini (Editor-in-Chief) and two anonymous referees are thanked for their detailed and insightful review comments, which helped to improve the manuscript.

\section{ARTICLE INFORMATION}

Manuscript ID: 20190030. Received on: 04/30/2019. Approved on: 12/16/2019.

All authors wrote the first and final drafts of the manuscript and prepared all figures and tables.

Competing interests: The authors declare no competing interests. 


\section{REFERENCES}

American Public Health Association (APHA). 1999. Standard Methods for the Examination of Water and Wastewater. 20. ed. Washington D.C., APHA.

Barth T.F.W. 1961. Abundance of the elements, areal averages and geochemical cycles. Geochimica et Cosmochimica Acta, 23(1-2):1-8. https:// doi.org/10.1016/0016-7037(61)90086-2

Boeglin J.L., Mortatti J., Tardy Y. 1997. Érosion chimique et mécanique sur le basin amont du Niger (Guinée, Mali). Bilan géochimique de l'altération en milieu tropical. Comptes Rendus de l'Academie des Sciences, Series IIA, 325(3):185-191. https://doi.org/10.1016/S1251-8050(97)88287-0

Boeglin J.I., Probst J.L. 1996. Transports fluviaux de matières dissoutes et particulaires sur un basin versant em région tropicale: le basin versant $\mathrm{Du}$ Niger au cours de la période 1990-1993. Science Géologique Bulletin, 49(14):25-45. https://doi.org/10.3406/sgeol.1996.1934

Boeglin J.I., Probst J.L. 1998. Physical and chemical weathering rates and $\mathrm{CO}_{2}$ consumption in a tropical lateritic environment: the upper Niger basin. Chemical Geology, 148(3-4):137-156. https://doi.org/10.1016/ S0009-2541(98)00025-4

Bonotto D.M., Fujimori K., Moreira-Nordemann L.M. 2007. Determination of weathering rate of the Morro do Ferro Th-REEs deposit, Brazil using U-isotope method. Applied Radiation and Isotopes, 65(5):474-481. http:// dx.doi.org/10.1016/j.apradiso.2006.11.003

Bortoletto Junior M.J. 2004. Características hidrogeoquímicas e processos erosivos mecânicos e químicos nas bacias de drenagem dos rios Tietê e Piracicaba. $\mathrm{PhD}$ Thesis, Centro de Energia Nuclear na Agricultura, Universidade de São Paulo, Piracicaba, 202 p.

Bortoletto Junior M.J., Mortatti J., Probst J.L. 2002. Erosão química na bacia hidrográfica do rio Corumbataí (SP). Geochimica Brasiliensis, 16(1):99-111. https://doi.org/10.21715/gb.v16i1.501

Brasil. Ministério das Minas e Energia. 1983. Projeto RADAMBRASIL. Folhas 23/24, Rio de Janeiro. Levantamento de Recursos Naturais, 32:27-247.

Chakrapani G.J. 2005. Factors controlling variations in river sediment loads. Current Science, 88(4):569-575.

Cherem L.F.S., Varajão C.A.C., Salgado A.A.R., Varajão A.F.D.C., Braucher R., Bourlés D., Magalhães Júnior A.P., Nalini Júnior H.A. 2012. Denudação química e rebaixamento do relevo em bordas interplanálticas com substrato granítico: dois exemplos no SE de Minas Gerais. Revista Brasileira de Geomorfologia, 13:73-84. http://dx.doi.org/10.20502/rbg.v13i1.344

Conceição F.T., Antunes M.L.P., Angelucci V.A., Moruzzi R.B., Navarro G.R.B. 2013. Rainwater chemical composition and annual atmospheric deposition in Sorocaba, (São Paulo State), Brazil. Revista Brasileira de Geofísica, 31(1):5-15. http://dx.doi.org/10.22564/rbgf.v31i1.242

Conceição F.T., Bonotto D.M. 2003. Use of U-isotopes disequilibrium to evaluate the weathering rates and fertilizer derived uranium at São Paulo State, Brazil. Environmental Geology, 44:408-418. http://dx.doi. org/10.1007/s00254-003-0775-4

Conceição F.T., Bonotto D.M. 2004. Weathering rates and anthropogenic influences in a sedimentarybasin, São Paulo State, Brazil. Applied Geochemistry, 19(4):575-591. http://dx.doi.org/10.1016/j.apgeochem.2003.07.002

Conceição F.T., Sardinha D.S., Godoy L.H., Fernandes A.M., Pedrazzi F.J.M. 2015. Influência sazonal no transporte específico de metais totais e dissolvidos nas águas fluviais da Bacia do Alto Sorocaba (SP). Geochimica Brasiliensis, 29(1):23-34. http://dx.doi.org/10.5327/Z0102-9800201500010003

Conceição F.T., Sardinha D.S., Navarro G.R.B., Antunes M.L.P., Agelucci V.A. 2011. Composição química das águas pluviais e deposição anual na bacia do Alto Sorocaba (SP). Química Nova, 34(4):610-616. http://dx.doi. org/10.1590/S0100-40422011000400011

Conceição F.T., Sardinha D.S., Souza A.D.G., Navarro G.R.B. 2010. Anthropogenic influences on annual flux of cations and anions at Meio Stream Basin, São Paulo State, Brazil. Water Air and Soil Pollution, 205:7991. https://doi.org/10.1007/s11270-009-0057-1

Couto Júnior A.A., Conceição F.T., Fernandes A.M., Spatti Júnior E.P., Lupinacci C.M., Moruzzi R.B. 2019. Land use changes associated with the expansion of sugar cane crops and their influences on soil removal in a tropical watershed in São Paulo State (Brazil). Catena, 172:313-323. https://doi.org/10.1016/j.catena.2018.09.001
Departamento de Águas e Energia Elétrica (DAEE). 2010. Banco de dados hidrológicos. Available at: <http://www.hidrologia.daee.sp.gov.br/>. Accessed on: Jun 15, 2016.

Dionex Corporation. 2004. ICS-90 ion chromatography system operator's manual. California: Dionex Corporation. (Document n.031851, revision 4).

Edmond J.M. 1970. High precision determination of titration alkalinity and total carbon dioxide content of seawater by potentiometric titration. DeepSea Research Part I: Oceanographic Research Papers, 17(4):737-750. https:// doi.org/10.1016/0011-7471(70)90038-0

Empresa Brasileira de Pesquisa Agropecuária (EMBRAPA). 2013. Sistema brasileiro de classificação de solos. 3. ed. Brasília, EMBRAPA.

Fernandes A.M. 2012. Características hidrogeoquímicas da bacia de drenagem do rio Sorocaba, SP: processos erosivos mecânicos e químicos. $\mathrm{PhD}$ Thesis, Centro de Energia Nuclear na Agricultura, Universidade de São Paulo, Piracicaba, 197 p.

Fernandes A.M., Conceição F.T., Spatti Junior E.P., Sardinha D.S., Mortatti J. 2016a. Chemical weathering rates and atmospheric/soil $\mathrm{CO}_{2}$ consumption of igneous and metamorphic rocks under tropical climate in southeastern Brazil. Chemical Geology, 443:54-66. https://doi.org/10.1016/j. chemgeo.2016.09.008

Fernandes A.M., Hissler C., Conceição F.T., Spatti Junior E.P., Mortatti J. 2016b. Combined analysis of trace elements and isotopic composition of particulate organic matter in suspended sediment to assess their origin and flux in a tropical disturbed watershed. Environmental Pollution, 218:844854. http://dx.doi.org/10.1016/j.envpol.2016.08.008

Fernandes A.M., Nolasco M.B., Hissler C., Mortatti J. 2012. Mechanical erosion in a tropical river basin in Southeastern Brazil: chemical characteristics and annual fluvial transport mechanisms. Journal of Geological Research, 8(1-2). http://dx.doi.org/10.1115/2012/127109

Gaillardet J., Dupre B., Allegre C.J., Négrel P. 1997. Chemical and physical denudation in the Amazon River Basin. Chemical Geology, 142(3-4):141173. https://doi.org/10.1016/S0009-2541(97)00074-0

Gaillardet J., Dupré B., Louvat P., Allègre C.J. 1999. Global silicate weathering and $\mathrm{CO}_{2}$ consumption rates deduced from the chemistry of large rivers. Chemical Geology, 159(1-4):3-30. https://doi.org/10.1016/ S0009-2541(99)00031-5

Gibbs R.J. 1970. Mechanisms controlling world river water chemistry. Science, 170(3962):1088-1090. https://doi.org/10.1126/ science.170.3962.1088

Godoy A.M., Hackspacher P.C., Oliveira M.A.F. 1996. Geologia da folha Sorocaba. Geociências, 15:89-110.

Gurumurthy G.P., Balakrishna K., Riotte J., Braun J.J., Audry S., Shankar H.N.U., Manjunatha B.R. 2012. Controls on intense silicate weathering in a tropical river, southwestern India. Chemical Geology, 300-301:61-69. https://doi.org/10.1016/j.chemgeo.2012.01.016

Hackspacher P.C., Ribeiro L.F.B., Ribeiro M.C.S., Fetter A.H., Hadler Neto J.C., Tello C.E.S., Dantas E.L. 2004. Consolidation and break-up of the South American platform in southeastern Brazil: tectonothermal and denudation histories. Gondwana Research, 7(1):91-101. https://doi.org/10.1016/ S1342-937X(05)70308-7

Hermes L.C., Silva A.S. 2004. Avaliação da qualidade das águas: manual prático. Brasília, Embrapa Informação Tecnológica, 55 p.

Hissler C., Hostache R., Iffly J.F., Pfister L., Stille P. 2015. Anthropogenic Rare Earth Element fluxes into floodplains: coupling between geochemical monitoring and hydrodynamic-sediment transport modelling. Comptes Rendus Geoscience, 347(5-6):294-303. https://doi.org/10.1016/j. crte.2015.01.003

Hissler C., Stille P., Iffly J.F., Guignard C., Chabaux F., Pfister L. 2016. Origin and dynamics of Rare Earth Elements during flood events in contaminated river basins: Sr-Nd-Pb evidence. Environmental Science \& Technology, 50(9):4624-4631. https://doi.org/10.1021/acs.est.5b03660

Instituto Brasileiro de Geografia e Estatística (IBGE). Dados do Censo 2010. Diário Oficial da União, Brasília, DF, 4 nov. 2010. Available at: <http:// www.ibge.gov.br/censo2010/dados_divulgados/index.php?uf $=35>$. Accessed on: Dec 3, 2010. 
Instituto de Pesquisas Tecnológicas (IPT). 2006. Relatório Zero da Bacia do Sorocaba e Médio Tietê - Atualização 2005. Relatório Técnico nº 80 401-205. São Paulo, IPT.

Johnson N.M., Likens G.E., Bormann F.H., Pierce P.S. 1968. Rate of chemical weathering of silicate minerals in New Hampshire. Geochimica et Cosmochimica Acta, 32(5):531-545. https://doi. org/10.1016/0016-7037(68)90044-6

Köppen W. 1948. Climatologia. Mexico, Fondo de Cultura Econômica, $478 \mathrm{p}$.

Laraque A., Moquet J.S., Alkattan R., Steiger J., Mora A., Adèle G., Castellanos B., Lagane C., Lopez J.L., Perez J., Rodriguez M, Rosales J. 2013. Seasonal variability of total dissolved fluxes and origin of major dissolved elements within a large tropical river: The Orinoco, Venezuela. Journal of South American Earth Sciences, 44:4-17. http://dx.doi.org/10.1016/j. jsames.2012.12.011

Lasaga A.C., Soler J.M., Ganor J., Burch T.E., Nagy K.L. 1994. Chemical weathering rate laws and global geochemical cycles. Geochimica et Cosmochimica Acta, 58(10):2361-2386. https://doi. org/10.1016/0016-7037(94)90016-7

Li S., Lu X.X., Bush R. 2014. Chemical weathering and $\mathrm{CO}_{2}$ consumption in the Lower Mekong River. Science of the Total Environment, 472:162-177. http://dx.doi.org/10.1016/j.scitotenv.2013.11.027

Louvat P., Gislason S.R., Allègre C.J. 2008. Chemical and mechanical erosion rates in Iceland as deduced from river dissolved and solid material. American Journal of Science, 308(5):679-726. http://dx.doi. org/10.2475/05.2008.02

Martin J.M., Meybeck M. 1979. Elemental mass-balance of material carried by major world rivers. Marine Chemistry, 7(3):173-206. https://doi. org/10.1016/0304-4203(79)90039-2

Meybeck M. 1987. Global chemical weathering of surficial rocks estimated from river dissolved loads. American Journal of Science, 287:401-428. https://doi.org/10.2475/ajs.287.5.401

Meybeck M., Laroche L., Dürr H.H., Syvitski J.P.M. 2003. Global variability of daily total suspended solids and their fluxes in rivers. Global and Planetary Change, 39(1-2):65-93. https://doi.org/10.1016/ S0921-8181(03)00018-3

Millot R., Gaillardet J., Dupré B., Allègre C.J. 2002. The global control of silicate weathering rates and the coupling with physical erosion: new insights from rivers of Canadian Shield. Earth and Planetary Science Letters, 196(1-2):83-98. https://doi.org/10.1016/ S0012-821X(01)00599-4

Moreira-Nordemann L.M. 1980. Use of ${ }^{234} U /{ }^{238} U$ disequilibrium in measuring chemical weathering rate of rocks. Geochimica et Cosmochimica Acta, 44(1):103-108. https://doi.org/10.1016/0016-7037(80)90180-5

Moreira-Nordemann L.M. 1984. Salinity and weathering rate of rocks in a semi-arid region. Journal of Hydrology, 71(1-2):131-147. https://doi. org/10.1016/0022-1694(84)90074-X

Mortatti J., Probst J.L. 2003. Silicate rock weathering and atmospheric/soil $\mathrm{CO}_{2}$ uptake in the Amazon basin estimated from river water geochemistry: seasonal and spatial variations. Chemical Geology, 197(1-4):177-196. https://doi.org/10.1016/S0009-2541(02)00349-2

Mortatti J., Probst J.L., Fernandes A.M., Mortatti B.C., Oliveira H. 2008. Influence of discharge on silicate weathering dynamics of the Tiete river basin: major cations and dissolved silica approach. Geochimica Brasiliensis, 22(1):15-26. https://doi.org/10.21715/gb.v22i1.275

Mortatti J., Probst J.L., Ferreira J.R. 1992. Hydrological and geochemical characteristics of the Jamari and Jiparana river basin (Rondonia, Brazil). GeoJournal, 26:287-296. https://doi.org/10.1007/BF02629808

Mortatti J., Vendramini D., Oliveira H. 2012. Avaliação da poluição doméstica fluvial na zona urbana do município de Piracicaba, SP, Brasil. Ambiente e Água, 7(2):110-119. http://dx.doi.org/10.4136/ambi-agua.846

Mortatti J., Victória R.L., Tardy Y. 1997. Balanço de alteração e erosão química na bacia amazônica. Geochimica Brasiliensis, 11(1):2-13. https:// doi.org/10.21715/gb.v11i1.12

Oliveira J.B., Camargo M.N., Rossi M., Calderano Filho B. 1999. Mapa pedológico do Estado de São Paulo: legenda expandida. Campinas, Instituto Agronômico; Rio de Janeiro, Embrapa-Solos, 64 p.
Pedrazzi F.J.M., Conceição F.T., Sardinha D.S., Moschini-Carlos V., Pompêo M. 2013. Spatial and temporal quality of water in the Itupararanga Reservoir, Alto Sorocaba basin (SP), Brazil. Journal of Water Resources and Protection, 5(1):64-71. http://dx.doi.org/10.4236/jwarp.2013.51008

Pedrazzi F.J.M., Conceição F.T., Sardinha D.S., Moschini-Carlos V., Pompêo M. 2014. Avaliação da qualidade de água do Reservatório de Itupararanga, bacia do Alto Sorocaba (SP). Geociências, 33(1):26-38.

Pedró G. 1966. Essais sur la caractérisation géochimique des différents processus zonaux résultant de l'altération de roches superficielles (cycle aluminosillicique). Comptes Rendus de l'Academie de Science de Paris, 262:1821-1831.

Perrota M.M., Salvador E.D., Lopes R.C., D’Agostinho L.Z., Peruffo N., Gomes S.D., Sachs L.L.B., Meira V.T., Garcia M.G.M., Lacerda Filho J.V. 2005. Mapa geológico do Estado de São Paulo, escala 1:750.000. São Paulo, Programa Geologia do Brasil - PGB, CPRM.

Probst J.L. 1986. Dissolved and suspended matter transported by the Girou River (France): mechanical e chemical erosion rates in a calcareous molasse basin. Journal des Sciences Hydrologiques, 31 (1):61-79. https://doi. org/10.1080/02626668609491028

Probst J.L. 1992. Géochimie et Hydrologie de l'Érosion Continentale. Mécanisms Bilan Global Actuel et Fluctuations au Cours des 500 Derniers millions d'annés. Sciences Géologiques Bulletin, 94:1-161.

Probst J.L., Nkounkou R.R., Krempp G., Bricquet J.P., Thiébaux J.P., Olivry J.C. 1992. Dissolved major elements exported by the Congo and the Ubangui rivers during the period 1987-1989. Journal of Hydrology, 135(14):237-257. https://doi.org/10.1016/0022-1694(92)90090-I

Ribani M., Bottoli C.B.G., Collins C.H., Jardim I.C.S.F., Melo L.F.C. 2004. Validação em métodos cromatográficos e eletroforéticos. Química Nova, 27(5):771-780. http://dx.doi.org/10.1590/S0100-40422004000500017

Riebe C.S., Kirchner J.W., Finkel R.C. 2004. Erosional and climatic effects on long-term chemical weathering rates in granitic landscapes spanning diverse climate regimes. Earth and Planetary Science Letters, 224(3-4):547-562. https://doi.org/10.1016/j.epsl.2004.05.019

Ross J.L.S. 1996. Geografia do Brasil. São Paulo, EDUSP, 546 p. v. 3.

São Paulo. 1991. Lei no 7.663/91 - Estabelece normas de orientação à Política Estadual de Recursos Hídricos bem como ao Sistema Integrado de Gerenciamento de Recursos Hídricos. Available at: <http://www.al.sp.gov. $\mathrm{br} /$ norma/?id=18836>. Accessed on: Jun 22, 2016.

Sardinha D.S., Bonotto D.M., Conceição F.T. 2010. Weathering rates at Alto Sorocaba basin, Brazil, using U-isotopes and major cations. Environmental Earth and Sciences, 61:1025-1036. http://dx.doi.org/10.1007/s12665-009-0424-7

Semhi K., Amiotte-Suchet P., Clauer N., Probst J.L. 2000. Impact of nitrogen fertilizers on the natural weathering-erosion process and fluvial transport in the Garonne basin. Applied Geochemistry, 15(6):865-878. https://doi. org/10.1016/S0883-2927(99)00076-1

Spatti Júnior E.P., Conceição F.T., Fernandes A.M., Sardinha D.S., Menegário A.A., Moruzzi R.B. 2019. Chemical weathering rates of clastic sedimentary rocks from the Paraná Basin in the Paulista Peripheral Depression, Brazil. Journal of South American Earth Science, 96:102369. http://dx.doi. org/10.1016/j.jsames.2019.102369

Stallard R.F., Edmond J.M. 1981. Geochemistry of the Amazon Basin. 1. Precipitation chemistry and marine contribution to the dissolved load at the time of peak discharge. Journal of Geophysical Research, 86(C10):98449858. https://doi.org/10.1029/JC086iC10p09844

Stallard R.F., Edmond J.M. 1983. Geochemistry of the Amazon Basin. 2. The influence of the geology and weathering environment on the dissolved load. Journal of Geophysical Research, 88(C14):9671-9688. https://doi. org/10.1029/JC088iC14p09671

Stallard R.F., Edmond J.M. 1987. Geochemistry of the Amazon Basin. 3. Weathering chemistry and limits to dissolved inputs. Journal of Geophysical Research, 92(C8):8293-8302.https://doi.org/10.1029/JC092iC08p08293

TardyY.1971.Characterizationoftheprincipalweatheringtypesbythegeochemistry of waters from some European and African crystalline massifs. Chemical Geology, 7(4):253-271.https://doi.org/10.1016/0009-2541(71)90011-8

Tchobanoglous G., Burton F.L. 1991. Wastewater engineering: treatment, disposal and reuse. 3. ed. New York, McGraw-Hill, 1334p.

Teixeira W., Toledo M.C.M., Fairchild T.R., Taioli F. 2000. Decifrando a Terra. São Paulo, Oficina de textos, 568p. 
Braz. J. Geol. (2020), 50(1): e20190030

United States Department of Agriculture (USDA). 1999. Soil Taxonomy - A basic system of soil classification for making and interpreting soils surveys. 2. ed. Washington, D.C., US Department of Agricultural Soil Conservation Service, 754p.

Walling D.E., Fang D. 2003. Recent trends in the suspended sediment loads of the world's rivers. Global and Planetary Change, 39(1-2):111-126. https://doi.org/10.1016/S0921-8181(03)00020-1
Weijden H.V., Pacheco F.A.L. 2006. Hydrogeochemistry in the Vouga River basin (central Portugal): Pollution and chemical weathering. Applied Geochemistry, 21(4):580-613. https://doi.org/10.1016/j. apgeochem.2005.12.006

White A.F., Blum A.E. 1995. Effects of climate on chemical weathering in watersheds. Geochimica et Cosmochimica Acta, 59(9):1729-1747. https:// doi.org/10.1016/0016-7037(95)00078-E 